\title{
Factors Influencing Financial Accountability in Ciamis Regency
}

\author{
Bena Balatin Sudarman ${ }^{1}$, Rizal Yaya ${ }^{2, *}$
}

\author{
${ }^{1}$ Department of Accounting, Faculty of Economics and Business, Universitas Muhammadiyah Yogyakarta, Indonesia \\ ${ }^{2}$ Department of Accounting, Faculty of Economics and Business, Universitas Muhammadiyah Yogyakarta, Indonesia \\ *Corresponding author. Email: r.yaya@umy.ac.id
}

\begin{abstract}
The lack of stakeholder participation in the budgeting process will raise asymmetric information in the use of public funds. Furthermore, corruption cases still increase even though internal controls and transformational leadership have been applied. Therefore, this research aims to examine and obtain empirical evidence on the influence of budgetary participation, accessibility of financial reports, internal control, and transformational leadership on regional financial accountability. The research data used primary data obtained from a questionnaire, and there was a total of 112 questionnaires. The hypothesis testing in this research employed a multiple linear regression model. The indicators of regional financial accountability utilized in this study were the indicators of the performance accountability system of government agencies from the Ministry of Administrative Reform and Bureaucracy Reform. The analysis demonstrated that financial reports' budgetary participation and accessibility had no positive effect on regional financial accountability, while internal control and transformational leadership positively affected regional financial accountability. The research results provide insight into local governments to increase the effectiveness of the budgetary participation system, accessibility of financial reports system, internal controls system, and the implementation of transformational leadership.
\end{abstract}

Keywords: financial accountability, budgetary participation, accessibility of financial reports, internal control, transformational leadership

\section{INTRODUCTION}

Indonesia is a unitary state that adheres to the principle of decentralization. Decentralization is the devolution of power from the central government to the local governments based on autonomy. In carrying out the regional autonomy system, local governments have an obligation to optimally manage their natural resources, human resources, and financial resources. The structure and procedures for administering regional government are regulated in the Law of Republic Indonesia. Law No. 23 of 2014 concerning Regional Government affirms that the implementation of regional government is to accelerate the realization of public welfare through improving services, empowerment, and community participation and increasing regional competitiveness by taking into account the principles of democracy, equity, justice, and distinctiveness of a region in the system of the Unitary State of the Republic Indonesia.

The government's main activity as the public sector is related to the supply of goods or services to meet public needs. In carrying out its activities, the central government and regional government certainly use public funds. Therefore, the government as the public sector is required to manage public funds economically, efficiently, and effectively to meet public needs optimally. In addition, the government is also required to provide a form of accountability in the use of public funds [1,2]. The government should record and report any use of public funds in the financial statements. It is in accordance with the stipulation of Law No. 17 of 2003 concerning State Finance and Law No. 1 of 2004 concerning State Treasury.

Accountability is always linked to good governance. Without good governance, human rights cannot be respected and protected sustainably. Good governance can control and manage public funds and ensure the realization of human rights, free from abuse of power and corruption, and obey the rule of law [3]. Good governance implementation can be achieved by applying a precise, clear, measurable, and legitimate accountability system to be effective and accountable for government administration and development. However, the current phenomenon regarding financial accountability is the finding of non-compliance with the provisions of laws and regulations that have financial impacts resulting in losses [4]

As stakeholders, the community has the right to obtain an explanation through accountability of budgeting, reporting, and disclosure of all government activities. Measuring a region's financial accountability can be seen from several factors, including budgetary participation, accessibility of 
financial reports, transformational leadership, and internal control. In using public funds, the first stage carried out by the government is planning and budgeting. The budget may also be regarded as a statement concerning the estimation of the performance to be achieved over a certain period by the financial institution's size [5].

Budgeting in the public sector is quite complex and contains political power. There are two main reasons why participatory budgeting is necessary $[5,6]$; first, the corporate superiors and subordinates in the participatory budgeting process will stimulate controlling asymmetric information and uncertainty of task. Second, participation in the budgeting process can reduce the weight and pressure of tasks, and the management will get job satisfaction, in which the positive impact will further improve its performance.

Aside from budgetary participation, the accessibility of financial reports is a prerequisite that can increase regional financial accountability. In this regard, the inability of financial statements to carry out accountability is not only caused by financial statements that do not contain all the relevant information needed by users but also because the report cannot be accessed easily by potential users [7]. Besides, financial statements are structured reports that provide information about the financial position and record all transactions carried out by an entity. Therefore, the financial statements of an entity should be easily accessible to the users of financial statements. Nevertheless, in reality, the ease of accessing financial statements still does not apply well. The general public still cannot access the government financial reports because there are certain conditions, such as letters of recommendation from lecturers or universities and research proposals. In fact, the good application of the financial accounting system and easy access for the public to obtain the information of financial reports greatly determines the transparency and accountability levels of regional finance [4].

Moreover, the organization's leadership takes a very important role in leading the organization to achieve its goal. Therefore, a leader is needed to influence his subordinates. Through transformational leadership, leaders are expected to engage their subordinates to increase regional financial accountability actively. Further, one of the government's efforts to achieve public accountability is internal control. The internal control is regulated in Government Regulation No. 60 of 2008 concerning the government's internal control system. Internal control within government organizations is often termed as management control [8]. Control over government administration is needed to achieve effective, efficient, transparent, and accountable management of the finances state [9].

Therefore, this study focuses on the performance of the Regional Apparatus Organization in Ciamis. In this case, several problems of regional financial accountability in Ciamis included the nonoptimal ability to operate SIPKD (Regional Financial Management Information System); accordingly, the public could not access the financial statements of the Ciamis Regency [10]. In addition, the opinions given by the Audit Board of Republic Indonesia (Badan Pemeriksa Keuangan) consist of Unqualified Opinion, Qualified Opinion, Adverse Opinion, And Disclaimer Opinion [11]. In 2014, the financial accountability target proclaimed by the government was that 60 percent of the total number of regional governments should obtain an unqualified opinion. Concerning this, Ciamis Regional Government's financial reports have received Unqualified Opinions since 2014. Besides, the Ciamis Regional Government has got a B for the performance of Ciamis accountability since 2017 , while in the previous year, it was awarded as CC.

Table 1. Audit Board of the Republic Indonesia opinion on local government financial reports and Ciamis predicates of SAKIP

\begin{tabular}{|l|c|c|}
\hline \multicolumn{3}{|c|}{ CIAMIS } \\
\hline Year & $\begin{array}{c}\text { Accountability of } \\
\text { financial } \\
\text { statements }\end{array}$ & $\begin{array}{c}\text { Performance } \\
\text { Accountability } \\
\text { System of } \\
\text { Government } \\
\text { Agencies (SAKIP) }\end{array}$ \\
\hline 2014 & Unqualified Opinion & CC \\
\hline 2015 & Unqualified Opinion & CC \\
\hline 2016 & Unqualified Opinion & CC \\
\hline 2017 & Unqualified Opinion & B \\
\hline 2018 & Unqualified Opinion & B \\
\hline
\end{tabular}

Source: Audit Board of the Republic of Indonesia and the Ministry of Administrative Reform and Bureaucracy Reform (processed)

On the other hand, the Corruption Perception Index (CPI) of Indonesia is currently very low. In 2018, Indonesia's Corruption Perception Index score was 38 [12]. If the CPI value is getting closer to zero, a country has many corruptions. In contrast, if the CPI score is close to 100, the country has no corruption cases. Based on the KPK (Commission of Corruption Eradication) annual report (2018), there were 121 people suspected of corruption. In addition, 19 regional heads were engaged in corruption cases. Out of 19 regional heads, five regional heads were from West Java. It demonstrates that corruption often happens in West Java. At the end of December (2019), three corruption cases were being handled by the Attorney General's Office Ciamis. The corruption cases were related to the budget for food and drink at Pangandaran Regional Election Commission, fingerprint attendance machines within the Education Office, UPTD (Regional Technical Implementation Unit), community health center, and Ciamis sub-districts, as well as the Situ Lengkong tourism object levy. This practice signifies that the internal controls applied have not guided the government towards a transparent and accountable bureaucracy. For this reason, this research aims to examine and obtain empirical evidence on the influence of budgetary participation, accessibility of financial reports, internal 
control, and transformational leadership on regional financial accountability.

\section{THEORETICAL FRAMEWORK AND HYPOTHESIS DEVELOPMENT}

\subsection{Stewardship Theory}

Donaldson and Davis (1991), in "Toward a Stewardship Theory of Management," described Stewardship Theory as a situation where management as stewards are not motivated by the individual interests but rather are aimed at the interests of the organization [13]. There is a strong relationship between organizational satisfaction and organizational success. Organizational success can be achieved by maximizing standardized utilities and principles so that the stewards and principal members will work together to achieve organizational interests. Stewardship theory can be used in accounting research in public sectors, such as government organizations and non-public organizations. Fundamental assumptions of stewardship theory [14] are shown in the following table.

Table 2. Fundamental Assumptions of Stewardship Theory

\begin{tabular}{|c|c|}
\hline Managers as & Stewards \\
\hline Model of human behavior & $\begin{array}{c}\text { Sociological and } \\
\text { psychological }\end{array}$ \\
\hline $\begin{array}{c}\text { Collectivistic, pro- } \\
\text { organizational, } \\
\text { trustworthy }\end{array}$ \\
\hline Managers motivated by & Principal's objectives \\
\hline Manager's and principal's & Interests converge \\
\hline Structures that & Facilitate and empower \\
\hline Owners' attitude & Risk propensity \\
\hline $\begin{array}{c}\text { Principal-manager } \\
\text { relationship based on }\end{array}$ & Trust \\
\hline
\end{tabular}

Source: Podrug (2011)

\subsection{Committee of Sponsoring Organizations of the Treadway Commission (COSO)}

In 1994, the Committee of Sponsoring Organizations of the Treadway Commission (COSO) issued the Internal Control-Integrated Framework to help businesses and other entities assess and enhance their internal control systems. The COSO cube represents the integrated perspective recommended by COSO for an organization to expand internal control, providing a more robust and extensive focus on the broader subject of enterprise risk management [15]. In addition, the COSO cube has three components. Through analyzing each part of the components, the cube can be best understood. The three objectives' columns show operations, reports, and conformity. The goals are intended to help a company focus on various aspects of internal control to help the management achieve its goals. The five components in rows represent what is needed to achieve the three objectives. An entity's organizational structure shall be represented by the third dimension. In order for the organization to achieve its objectives, internal control must be effective and integrated to all levels of the organization.

\subsection{Hypothesis Development}

Budget plays an important role in public sector organizations, considering that the budget includes planning, controlling, and public accountability aspects. Involvement in the budgeting process will help the process of achieving the goals set by the organization. When employees are involved in the budgeting process (their opinions or inputs are considered in the preparation of the final budget), it will be followed by a heightened sense of self-belonging to the individual [9]. An increase in self-belonging will increase the sense of personal responsibility for achieving the level of the agency budget. For example, in the scope of Pekalongan Regional Government agencies, budget participation supports this statement by concluding that participation in budgeting positively affected performance accountability [16]. Meanwhile, Hayuwati and Halim (2018) found that participation in budgeting did not positively affect the financial accountability of the Klaten Regency. Based on the analysis above, the following hypothesis can be formulated:

$\mathbf{H}_{\mathbf{1}}$ : Budgeting participation has a positive effect on regional financial accountability.

The presentation and accessibility of regional financial reports positively and significantly affect transparency and accountability in regional financial management [17]. In addition, research by Nurrizkiana, Handayani, and Widiastuty (2017) provided evidence that the accessibility of regional financial reports had a positive and significant effect on the accountability of regional financial management [1]. In this regard, the government (stewards) has a mandate from the public (principal) to manage public funds effectively. Therefore, the public has the right to know how the government manages finance in providing services to the public. The ease of accessibility of financial statements can increase the accountability of regional finances, facilitating the public to assess the government's performance and achievement. Based on the analysis above, the following hypothesis can be proposed:

$\mathbf{H}_{2}$ : Accessibility of financial statements has a positive effect on regional financial accountability

Prior research stated that internal control has a positive effect on public accountability [9,18]. A good internal control system will profit an organization in averting the incidence of bad financing and helping the organization work successfully and incongruently while detecting errors and irregularities in its operation [19]. The internal control system also provides an emphasis on accountability. Therefore, its practice in the public sector seems crucial at any stage in enhancing accountability in the public sector organization [20]. The Government Internal Control System is an internal control 
system carried out comprehensively in the central and regional government environment [21]. Weak internal control systems will have a negative impact on performance that will ultimately reduce financial accountability. Based on the description of the theory that has been reviewed, the research hypothesis can be put forward as follows:

$\mathbf{H}_{3}$ : Internal control has a positive effect on regional financial accountability.

The dynamic of transformational leadership involves strong personal identification with the leader, joining in a shared vision of the future, or going beyond the self-interest exchange of rewards for compliance [22]. There are accountability connections with the integrity system, internal control system, and leadership qualities [23]. However, organizational commitment and transformational leadership have proven not to moderate the effect of accountability on the performance of public primary schools on Nias Island [24]. Supposedly, transformational leadership integrates views or creative insights, perseverance and energy, intuition, and sensitivity to the needs of others to integrate other cultural strategies into their organizations $[25,26]$. The idea of COSO stated that if the performance of leaders and subordinates in an organization goes well, then all components will be builtin and permeated in the management process. COSO recognizes a "tone on the top"; therefore, the organization's leadership has a very important role in leading the organization to achieve the organization's goal. Marques (2010) pointed out several characteristics of a leader, such as conforming morals and values, highly ethical, honoring integrity, honesty, and trust, full of respect, passion, commitment, compassion, justice, kindness, forgiveness, courage, love, deep listening, inspired and inspiring, authenticity, multi-dimensional, and amendable to change [27]. Based on the analysis above, the following hypothesis can be formulated:

$\boldsymbol{H}_{4}$ : Transformational leadership has a positive effect on regional financial accountability.

\section{RESEARCH METHOD}

The research was carried out in Ciamis Regency. The research sample consisted of employees of the Regional Apparatus Organization in Ciamis. The type of data used in this study was primary data. The data in this study were collected using a questionnaire distributed and filled out by 112 respondents. The sampling method employed in this study was a purposive sampling method with a judgment sampling technique in the form of sampling with certain criteria. The considerations utilized in selecting respondents to be sampled in this study were the chief or staff of the financial sub-division or the chief or staff of the planning subdivision with work experience of at least one year within the institution.

The data collection technique used in this study was the closed questionnaire technique. Questionnaires are several questions about factual data or opinions of respondents, which are considered facts and need to be answered by respondents [28]. The data collection was in one time/period that involved many samples (cross-sectional) in the real environment (no contrived settings).

This study consisted of four independent variables: budgetary participation, accessibility of financial reports, internal control, and transformational leadership. The research instrument of budgetary participation was developed based on the research instrument by Irfan, Santoso, Effendi (2017) [29] and Hayuwati and Halim (2018) [9]. Then, the research instrument of accessibility of financial reports and internal control was developed based on the research instrument by Hayuwati and Halim (2018). Besides, the research instrument of transformational leadership was developed based on the research instrument by Halid (2007) and Zulfitrianti (2017) [30]. The research variables were measured using a Likert scale 1-5 with the type of interval scale, with a score of one as the lowest value and five as the highest value.

Meanwhile, the dependent variable in this study was regional financial accountability, which was determined using a questionnaire developed by Krina (2003) [31] with a 1-5-point Likert scale. The dependent variable was measured by the indicators of the performance accountability system of government agencies from the Ministry of Administrative Reform and Bureaucracy Reform.

Moreover, a questionnaire is considered legitimate if the questions are truly suited for measuring what needs to be measured [32] (Nazaruddin and Basuki, 2019). The validity of this research instrument was determined using the Pearson Product Moment. The researchers then conducted the reliability test to measure the same phenomenon with consistent measurement results even if done repeatedly or under different conditions [33] (Sugiyono, 2012). In addition, the hypothesis testing in this research employed a multiple linear regression model. Multiple regression analysis is usually used to determine whether there is an influence between independent and dependent variables [34]. In multiple regression analysis, there was more than one independent variable to be tested. Thus, the relationship between the independent variables and the dependent variable is formulated in the equation model as follows:

$$
\beta_{0}+\beta_{1} B P+\beta_{2} A F R+\beta_{3} T L+\beta_{4} I C+e
$$

\section{RESEARCH RESULTS AND ANALYSIS}

Based on Ciamis Regional Regulation No. 8 of 2016, there are 28 Regional Apparatus Organizations. Therefore, the questionnaires were distributed to all Regional Apparatus Organizations in Ciamis Regency. Data collection was carried out by distributing questionnaires directly to the Head of Agency, Head of Financial Subdivision, and Head of Planning Subdivision.

As seen in Table 3, 112 questionnaires were disseminated, but 19 questionnaires could not be processed. Nineteen 
questionnaires that could not be processed were declared invalid because several question items were not answered, and some respondents' identities (besides names of respondents) were not filled out. Then, out of the 112 questionnaires distributed, only 93 questionnaires could be processed.

Table 3. Questionnaire Rate of Return

\begin{tabular}{|l|l|l|}
\hline \multicolumn{1}{|c|}{ Questionnaire } & Amount & Percentage \\
\hline Questionnaire sent & 112 & $100 \%$ \\
\hline $\begin{array}{l}\text { The questionnaire that } \\
\text { cannot be processed }\end{array}$ & 19 & $16.96 \%$ \\
\hline $\begin{array}{l}\text { The questionnaire that } \\
\text { can be processed }\end{array}$ & 93 & $83.04 \%$ \\
\hline
\end{tabular}

Source: Primary Data Processed, 2019

\subsection{Quality Test and Data Instrument}

A validity test was done to determine how valid the question item was in measuring the variables. An item can be said to be valid if the value of r-score $>$ r-table (0.2039). The validity test results stated that all question items in this study had a correlation value $\geq 0.2039$. Therefore, all question items in this study were declared valid. In addition, Cronbach's alpha values of variables budgetary participation, accessibility of financial reports, internal control, transformational leadership, and regional financial accountability were $>0.7$. It shows that all variables had fairly high reliability. Therefore, all variables could be declared reliable.

The classic assumption test is one of the requirements that must be met before conducting the multiple linear regression analysis. In this study, the classical assumption test is as follows. The normality test result showed that the sig value of 0.200 or 20 percent was greater than the $\alpha$ value of 0.05 or 5 percent. Thus, it can be concluded that the residuals were normally distributed. Based on the multicollinearity test, all variables had a tolerance value $>0.10$ and a VIF value $<10$. These results indicate that the regression model did not experience multicollinearity between independent variables. Moreover, based on the heteroscedasticity test, all independent variables had a significant value of more than 0.05 . It proves that the regression equation model did not experience heteroscedasticity, so it was feasible to predict regional financial accountability based on the independent variables influencing it.

\subsection{Research Results}

\subsubsection{Multiple Regression Analysis.}

Hypothesis testing was carried out using multiple linear regression. The test examined the influence of the independent variables (X), consisting of budgeting participation $\left(\mathrm{X}_{1}\right)$, accessibility of financial report $\left(\mathrm{X}_{2}\right)$, internal control $\left(\mathrm{X}_{3}\right)$, and transformational leadership $\left(\mathrm{X}_{4}\right)$ on regional financial accountability (Y) variables. The regression equation is:

$\mathrm{RFA}=4,815+(-0,030 \mathrm{BP})+0,106 \mathrm{AFR}+0,250 \mathrm{IC}+0,267 \mathrm{TL}$ $+\mathrm{e}$

\subsubsection{Determinant Coefficient Test (Adjusted $\boldsymbol{R}^{2}$ )}

The result of Adjusted $R^{2}$ is:

Table 4. Determinant Coefficient Regression Test

\begin{tabular}{|l|c|l|l|l|}
\hline Model & R & R Square & $\begin{array}{c}\text { Adjusted } \\
\text { R Square }\end{array}$ & $\begin{array}{c}\text { Std. Error } \\
\text { of the Estimate }\end{array}$ \\
\hline 1 & .727 a & .528 & .506 & 2.224 \\
\hline
\end{tabular}

Table 4 above shows that the adjusted $R^{2}$ value was 0.506. Therefore, 50.6 percent of the regional financial accountability variable could be explained by the independent variables: budgetary participation, accessibility of financial reports, internal control, and transformational leadership. However, the remaining 49.4 percent were explained by other variables that did not exist in this study.

\subsubsection{Simultaneous Test (F-Test)}

The result of the simultaneous test is:

Table 5. Simultaneously Significant Test (F - Test)

\begin{tabular}{|l|l|l|l|l|l|}
\hline \multicolumn{1}{|c|}{ Model } & $\begin{array}{c}\text { Sum of } \\
\text { Squares }\end{array}$ & Df & $\begin{array}{c}\text { Mean } \\
\text { Square }\end{array}$ & F & Sig. \\
\hline \multicolumn{1}{|c|}{$\begin{array}{l}\text { Regression } \\
1\end{array}$ Residual } \\
$\begin{array}{l}\text { Total } \\
\text { Total }\end{array}$ & 436.730 & 4 & 121.683 & 24.597 & $000 \mathrm{~b}$ \\
\hline
\end{tabular}

The test results display a significance level of $0.000<0$ (0.05), so it can be said that all of the independent variables, including budgetary participation, accessibility of financial report, internal control, and transformational leadership, jointly or simultaneously influenced regional financial accountability.

\subsubsection{Partial Test (T-Test)}

The result of the partial test is:

Table 6. Partial Test (T-Test)

\begin{tabular}{|l|l|l|l|}
\hline \multirow{2}{*}{ Model } & \multicolumn{2}{|l|}{$\begin{array}{l}\text { Unstandardized } \\
\text { Coefficients }\end{array}$} & \multirow{2}{*}{ Sig } \\
\cline { 2 - 4 } & B & Std. Error & \\
\hline (Constant) & 4.815 & 3.145 & .129 \\
\hline $\begin{array}{l}\text { Budgetary Participation } \\
(\mathrm{X} 1)\end{array}$ & -.030 & .062 & .632 \\
\hline $\begin{array}{l}\text { Accessibility of Financial } \\
\text { Report (X2) }\end{array}$ & .106 & .078 & .178 \\
\hline
\end{tabular}




\begin{tabular}{|l|l|l|l|}
\hline \multirow{2}{*}{ Model } & \multicolumn{2}{|l|}{$\begin{array}{l}\text { Unstandardized } \\
\text { Coefficients }\end{array}$} & \multirow{2}{*}{ Sig } \\
\cline { 2 - 3 } & B & Std. Error & \\
\hline Internal Control (X3) & .250 & .077 & .002 \\
\hline $\begin{array}{l}\text { Transformational } \\
\text { Leadership (X4) }\end{array}$ & .267 & .051 & .000 \\
\hline
\end{tabular}

In this study, financial reports' budgetary participation and accessibility did not affect regional financial accountability, while internal control and transformational leadership positively affected regional financial accountability. Therefore, based on Table 6 above, the hypothesis testing results are as follows:

\section{Hypothesis $1\left(\mathrm{H}_{1}\right)$}

The budgetary participation variable had a significance value of $0.632>\alpha(0.05)$ with a coefficient value of -0.030 . Then, it can be concluded that budgetary participation had no negative effect on regional financial accountability. The result indicates that $\mathbf{H}_{\mathbf{1}}$ was rejected.

\section{Hypothesis $2\left(\mathrm{H}_{2}\right)$}

The accessibility of the financial report variable had a significance value of $0.178>\alpha(0.05)$ with a coefficient value of 0.106 . It can be denoted that the accessibility of financial reports had a positive effect on regional financial accountability. The result signifies that $\mathbf{H}_{2}$ was rejected.

\section{Hypothesis $3\left(\mathrm{H}_{3}\right)$}

The internal control variable had a significance value of $0.002<\alpha(0.05)$ with a coefficient value of 0.250 . It can be concluded that internal control had a positive effect on regional financial accountability. The result shows that $\mathbf{H}_{3}$ was accepted.

\section{Hypothesis $4\left(\mathrm{H}_{4}\right)$}

The transformational leadership variable had a significance value of $0.000<\alpha(0.05)$ with a coefficient value of 0.267 . It can be inferred that transformational leadership had a positive effect on regional financial accountability. The result means that $\mathbf{H}_{\mathbf{4}}$ was accepted.

\section{DISCUSSION}

\subsection{The Effect of Budgetary Participation on Regional Financial Accountability}

The results of multiple linear regression tests showed that the variable of budgetary participation did not positively affect regional financial accountability in Ciamis Regency. It means the level of involvement of employees in the preparation of the budget would not affect regional financial accountability improvement.

The results of this study are not in line with research conducted by Zeyn (2011), which revealed that good governance (in which there is a participation dimension) influenced financial accountability with organizational commitment as moderating [35]. The results of this study also do not support the theory, putting forward that involving individuals in budgeting will increase accountability in financial management. Concerning this, the process of budgeting at the local government is a fairly complicated stage and involves government work units [36]. This study's lack of participation in budgeting on financial accountability was allegedly due to indications of pseudo participation in budget preparation. The practice of pseudo participation in budgeting is a condition where superiors give freedom to subordinates to provide input in the budgeting process actively, but such participation is ignored/under-taken into consideration in the final budget decision [9].

Pseudo-participation practices could be seen by comparing the respondents' responses to the questionnaire in the research instrument. Respondents tended to agree on the indicator of the frequency of discussions related to the budget with superiors. Thus, it can be concluded that subordinates actively contributed to the budgeting process. However, compared to the indicators related to the magnitude of influence on the final budget, the average respondent answered neutrally. Thus, when viewed from the magnitude of influence on the final budget determination, the respondent was not sure of their influence in the final budget decision. It can be concluded that the high freedom of subordinates to provide input on the budget was not accompanied by a high influence of the employee on the final budget determination.

\subsection{The Effect of Accessibility of Financial Reports on Regional Financial Accountability}

The results of multiple linear regression tests revealed that the accessibility of financial reports had no positive effect on regional financial accountability. In other words, the assessment of regional financial accountability was not caused by the level of accessibility of financial reports. In fact, the ease of use of IT to access the existing mass media should add the ease to access local government financial reports [37]. However, the results of this study do not support the theory, stating that the ease of accessing financial reports can increase regional financial transparency and accountability by local governments that the people have chosen. The inability of financial statement accessibility to influence the financial accountability in this study was alleged because the research respondents tended to have quite high access to the financial report. Respondents consisted of employees of the financial subdivision and employees of the planning subdivision of the Regional Apparatus Organization as internal stakeholders in Ciamis Regency, which had fairly high access to the financial report of the local government. The high accessibility of financial reports occurred because research respondents were directly involved with the financial report preparation process.

Nevertheless, the high level of accessibility of local government financial reports was not necessarily followed by increased assessments of financial management accountability. Although respondents tended to have high 
financial report accessibility, each respondent's assessment of accountability in regional financial management actually had a quite high variation. This difference in financial management accountability assessment was caused by differences in the demands of accountability from each individual. The higher demand for accountability in regional financial management, the higher the criteria used to assess regional financial management. Regional financial management that some respondents considered quite clear was likely to be considered less clear by other respondents who demanded higher accountability.

\subsection{Effect of Internal Control on Regional Financial Accountability}

The multiple linear regression test results uncovered that internal control positively affected the regional financial accountability in the Regional Apparatus Organization of Ciamis Regency. These results indicate that internal control would increase along with increased accountability of regional finances. Based on theoretical support and empirical evidence, the internal control system positively and significantly affected financial accountability [38]. Furthermore, the internal control system had a positive and significant effect on the accountability of regional financial management [39]. In the context of governance organizations, local government as an agent chosen by the community must provide, present, and report all financial and non-financial works to the public.

The results of this study also reinforced the theory explaining that an internal control system is needed to achieve effective, efficient, transparent, and accountable financial management. Internal control represents the organization's plans, methods, and procedures to achieve its mission, goals, and objectives, then serves as the first line of defense in safeguarding assets and preventing and detecting fraud, waste, misuse, errors, and mismanagement. The internal control system is also needed to help ensure that the local government in carrying out the regional financial management is under the laws, policies, and related objectives so that the information presented by the local government to the public truly represents the implementation of the mandate that has been carried out clearly.

\subsection{The Effect of Transformational Leadership on Regional Financial Accountability}

The multiple linear regression test results showed that the transformational leadership variable positively affected regional financial accountability in Ciamis Regency. It means that the implementation of transformational leadership would align with an increase in regional financial management accountability. This research is in line with the research of Aziz et al. (2015), who found connections of accountability with the integrity of the system, internal control systems and leadership qualities [20]. Research by Aimbu, Saerang and Gamaliel (2016) also stated that transformational leadership positively affected regional financial management accountability [40]. Furthermore, Kakisina and Bastian's (2018) research found that organizational commitment and transformational leadership have proven not to moderate the effect of accountability on the performance of public primary schools in Nias Island [24].

Moreover, the results of this study agree with the theory that transformational leadership can increase the regional financial accountability by local governments that the people have chosen. In this regard, leadership dimensions are divided into four dimensions: idealized influence, inspirational motivation, individualized consideration, and intellectual stimulation $[25,26]$. Leaders can influence the use of all available resources for policy implementation through the four dimensions. A leader also has the capacity to compel the use of other resources. Therefore, a leader must be able to have a way to move employees and the community to achieve goals.

\section{CONCLUSION AND SUGGESTION}

Based on testing and analysis that have been done, this study's conclusion is:

1. At the significance level of 5 percent, budgetary participation had no positive effect on regional financial accountability in Ciamis Regency. In other words, the level of involvement of employees in the preparation of the budget would not affect regional financial accountability improvement.

2. At the significance level of 5 percent, the accessibility of financial reports did not positively affect the regional financial accountability in the Ciamis Regency. In other words, the assessment of financial management accountability of research respondents was not caused by the level of accessibility of financial reports.

3. At the significance level of 5 percent, internal control had a significant positive effect on regional financial accountability in Ciamis Regency. These results indicate that internal control would increase along with increased accountability in the management of regional finances.

4. At the significance level of 5 percent, transformational leadership had a significant positive effect on regional financial accountability in Ciamis Regency. It shows that the implementation of transformational leadership would align with an increase in regional financial management accountability.

However, the accountability assessment in the management of regional finances in this study resulted from an analysis of the perception of internal stakeholders. Some questionnaires were addressed through the secretariat of each regional service so that they could not provide an understanding of the purpose of the statements in the 
questionnaire to respondents. The independent variables in this study were also limited, consisting of budgeting participation (X1), accessibility of financial report (X2), internal control (X3), and transformational leadership (X4), so that the independent variables in this study could not fully explain the dependent variable

In the practice of regional financial management, the government of Ciamis Regency is expected to continuously improve the quality of the internal control of the regional apparatus as a whole to improve financial accountability. Besides improving the government's internal control in Ciamis Regency, it is expected to implement transformational leadership to affect employee performance and increase regional financial accountability. Furthermore, the Ciamis Regency government can increase participation in budgeting and develop slowly towards non-apparent participatory budgeting. This study's results indicate that the accessibility of financial statements had no significant effect on financial accountability. Nevertheless, the government of Ciamis Regency is expected to continue to increase public accessibility to the financial statements that are public rights and are a form of accountability [41]. The more published a financial statement is, the faster and easier the users of financial statements obtain financial information that can be used as an economic, social, and political decision consideration.

\section{ACKNOWLEDGMENTS}

The researchers thank Dr. Ahim Abdurahim (Head of Accounting Department) and Evi Rahmawati for helpful comments to improve this work. The researchers also acknowledge helpful discussions with the lectures of Faculty Economics and Business in Universitas Muhammadiyah Yogyakarta.

\section{REFERENCES}

[1] B. Nurrizkiana, L. Handayani, E. Widiastuty, Determinan Transparansi dan Akuntabilitas Pengelolaan Keuangan Daerah dan Implikasinya Terhadap Kepercayaan Public-Stakeholders. Jurnal Akuntansi dan Investasi, 2017, 18 (1): 28-47. http://dx.doi.org/ 10.18196 /jai.18159.

[2] N.L. Yuliani, B. Susanto, Partisipasi Anggaran dan Kinerja Managerial di Pemerintah Daerah: Anteseden dan Pemediasi, Jurnal Akuntansi dan Investasi, 2018, 19(1).

[3] Good Governance and Human Rights, 2012, Retrieved 09 14, 2019, from United Nations Human Rights: http://www.ohchr.org/en/Issues/Development/ GoodGovernance/Pages/GoodGovernanceIndex.aspx

[4] M. Ichlas, H. Basri, M. Arfan, Pengaruh Penerapan Standar Akuntansi Pemerintahan, Sistem Pengendalian Intern Pemerintah dan Aksesibilitas Laporan Keuangan Terhadap Akuntabilitas Keuangan Pemerintah Kota Banda Aceh. Jurnal Magister Akuntansi, 2014, III.
[5] S.H.A. Kahar, A. Rohman, and A. Chariri, "Participative Budgeting, Budgetary Slack and Job Satisfaction In The Public Sector", JABR, vol. 32, no. 6, pp. 1663-1674, Nov. 2016.

[6] Tahar, A and Hanggit Her Kuncahyo, H H., Pengaruh Komitmen Organisasi, Partisipasi Penyusunan Anggaran, dan Kompensasi terhadap Kinerja Instansi Pemerintah Daerah, Reviu Akuntansi dan Bisnis Indonesia, 2020, 4(2)

[7] Steccolini, Ileana, Local Government Annual Report: an Accountability Medium? 2002.

[8] C.L. Kewo, The Effect of Participative Budgeting, Budget Goal Clarity and Internal Control Implementation on Managerial Performance. Research Journal of Finance and Accounting, 2014, 5(12), 81-87

[9] T. Hayuwati, A. Halim, Pengaruh Partisipasi Penyusunan Anggaran, Aksesibilitas Laporan Keuangan, dan Pengendalian Internal Terhadap Pertanggungjelasan Keuangan Daerah Kabupaten Klaten. Simposium Nasional Akuntansi XXI, Samarinda, 2018.

[10] M. Apip, F. Maesaroh, Pengaruh Aksesibilitas Laporan Keuangan Pemerintah Daerah Terhadap Transparansi Laporan Keuangan Pada Pemerintah Daerah Kabupaten Ciamis. Jurnal Wawasan dan Riset Akuntansi, 2016.

[11] Undang-Undang No. 15 Tahun 2004 tentang Pemeriksaan Pengelolaan dan Tanggung Jawab Keuangan Negara.

[12] Transparency International, Corruption Perception Index. Annual report, 2018.

[13] L. Donaldson, J.H. Davis, Stewardship Theory or Agency Theory: CEO Governance and Shareholder Returns. Australian Journal of Management, 1991. 16.

[14] N. Podrug, The Strategic Role of Managerial Stewardship Behaviour for Achieving Corporate Citizenship, Economic Pregled, 2011.

[15] COSO, Internal Control-Integrated Framework, Executive Summary, May 2013, p. 6.

[16] Arifin, Solikhun, Pengaruh Partisipasi Penyusunan Anggaran terhadap Kinerja Aparat Pemerintah Daerah: Komitmen Organisasi, Budaya Organisasi, dan Gaya Kepemimpinan sebagai Variabel Moderasi, Thesis, Universitas Diponegoro, 2012.

[17] P.S. Wahyuni, N.L.G Sulindawati, Erni, H.N. Trisna, Pengaruh penyajian laporan keuangan daerah dan aksesibilitas laporan keuangan daerah terhadap akuntabilitas pengelolaan keuangan daerah (studi empiris pada pemerintahan Kabupaten Badung). e-Journal Akuntansi Universitas Pendidikan Ganesha, 2014.

[18] N. Hamidi, Analisis Akuntabilitas Publik dan Kinerja Organisasi Pengelola Zakat Berdasarkan Aspek Pengendalian Intern dan Budaya Organisasi: Survei pada Organisasi Pengelola Zakat di Indonesia. Master Thesis. Universitas Gadjah Mada, Yogyakarta, 2009.

[19] S. Wardiwiyono, Internal control system for Islamic micro financing: An exploratory study of Baitul Maal wat Tamwil in the City of Yogyakarta Indonesia. International Journal of Islamic and Middle Eastern Finance and Management, 2012. 
[20] P. Krina, "Indikator dan Alat Ukur Prinsip Akuntabilitas dan Transparansi dalam pencapaian Good Governance", Sekertariat Good Public Governance Badan Perencanaan Pembangunan Nasional LAN dan BPKP, Jakarta, 2003.

[21] R. Yaya, and H.S. Suprobo, Determinants of Weaknesses in Internal Control of Provincial Government in Indonesia, Journal of Accounting and Investment, 2019 20(3)

[22] J.J. Hater, B.M. Bass, Superiors' Evaluations and Subordinates' Perceptions of Transformational and Transactional Leadership. Journal of Applied Psychology, 1988.

[23] M.A. Abd Aziz, H. Ab Rahman, M.M. Alam, J. Said, Enhancement of the accountability of public sectors through integrity system, internal control system and leadership practices: A review study. Procedia Economics and Finance, 2015, 28, 163-169. https://doi.org/10.1016/S22125671(15)01096-5

[24] S.M. Kakisina, I. Bastian, Pengaruh akuntabilitas terhadap kinerja sekolah dengan komitmen organisasi dan kepemimpinan transformasional sebagai pemoderasi (studi pada sekolah dasar negeri di pulau Nias), Simposium Nasional Akuntansi XXI, Samarinda, 2018

[25] B.M. Bass, and Avolio, Transformational Leadership and Organizational Culture, Public Administration Quarterly, 1993.

[26] B.M. Bass, B.J. Avolio, D.I. Jung and Y. Berson, "Predicting Unit Performance by assessing transformational and transactional leadership", Journal of Applied Psychology, 2003.

[27] J.F. Marques, Awakened leaders: born or made? Leadership and Organization Development Journal, 2010, 31(4), 307-323.

[28] S. Anwar, Pemahaman Individu, Observasi, Checklist, Interviu, Kuesioner dan Sosiometri. Yogyakarta: Pustaka Pelajar. 2009.

[29] M. Irfan, B. Santoso, L. Effendi, Pengaruh Partisipasi Anggaran Terhadap Senjangan Anggaran dengan Asimetri Informasi, Penekanan Anggaran dan Komitmen Organisasional sebagai Variabel Pemoderasi. Jurnal Akuntansi dan Investasi, 2016. 17(2):158-175. http://dx.doi.org/10.18196/jai.2016.0052. 158-175.

[30] Arwanto and Anggraini W, Public Participation, Transparency - The Utilisation of social media: Bandung City, Jurnal Studi Pemerintahan, 2018, 9(1)

[31] L.L. Krina, Indikator dan Alat Ukur Prinsip Akuntabilitas, Transparansi dan Partisipasi, Badan Perencanaan Pembangunan Nasional, Jakarta, 2003.

[32] I. Nazzaruddin, A.T. Basuki, Analisis Statistik dengan SPSS, Yogyakarta: Danisa Media, 2019.

[33] Sugiyono, Metode Penelitian Kuantitatif, Kualitatif dan RandD, Bandung: CV Alfabeta, 2012.

[34] Ghozali, Application of multivariate analysis with SPSS program. Semarang: Diponegoro University Publishing Agency, 2011.
[35] Zeyn, Elvira, Pengaruh Good Governance dan Standar Akuntansi Pemerintahan Terhadap Akuntabilitas Keuangan dengan Komitmen Organisasi Sebagai Pemoderasi. Jurnal Reviu Akuntansi dan Keuangan, 2011.

[36] I. Nazaruddin, H. Setyawan, Pengaruh Partisipasi Penyusunan Anggaran Terhadap Kinerja Aparat Pemerintah Daerah Dengan Budaya Organisasi, Komitmen Organisasi, Motivasi, Desentralisasi, dan Job Relevant Information Sebagai Variabel Moderasi. Akuntansi dan Investasi, 2012, 12.

[37] Zulfitrianti, Pengaruh Kepemimpinan Transformasional Terhadap Work Engagement Karyawan Universitas Muhammadiyah Yogyakarta (UMY), Undergraduate thesis. Yogyakarta. Universitas Muhammadiyah Yogyakarta, 2017.

[38] D. Ramon, Pengaruh Sistem Pengendalian Intern Terhadap Akuntabilitas Keuangan (Studi Empiris Pada Inspektorat Kota Se Provinsi Sumatera Barat. Jurnal Akuntansi, 2014, 2(2).

[39] A. Pramudita, Pengaruh Penerapan Standar Akuntansi Pemerintah Value for Money dan Sistem Pengendalian Intern Terhadap Akuntabilitas Pengelolaan Keuangan Daerah (Studi Empiris pada Organisasi Pemerintah Daerah (OPD) Kabupaten Ponorogo). Undergraduate thesis. Ponorogo. Universitas Muhammadiyah Ponorogo, 2017.

[40] L.L. Aimbu, D.P.E. Saerang, H. Gamaliel, Analisis determinan akuntabilitas pengelolaan keuangan daerah (Studi Empiris pada SKPD Pemerintah Kabupaten Kepulauan Talaud). Jurnal Riset Akuntansi dan Auditing "Goodwill”, 2017, 8(1).

[41] Mardiasmo, Akuntansi Sektor Publik, Yogyakarta: CV Andi, 2009.

[42] Peraturan Pemerintah No. 71 Tahun 2010 Tentang Standar Akuntansi Pemerintah

[43] Republik Indonesia, Peraturan Pemerintah No. 60 Tahun 2008, "Tentang Sistem Pengendalian Intern Pemerintah", Republik Indonesia, Jakarta, 2008. 